\title{
Partial Characterization of Bacteriophages from Indonesia and its Potency as Biocontrol of Xanthomonas oryzae pv. oryzae
}

\author{
Desi Rejeki ${ }^{1}$, Hardian Susilo Addy ${ }^{1,2,4 *}$ and Erlia Narulita ${ }^{1,3}$ \\ ${ }^{1}$ Post-Graduate Program, Study Program of Magister Biotechnology, University of Jember, East Java 68121, Indonesia \\ ${ }^{2}$ Division of Biology Molecule and Biotechnology, Center for Development of Advanced Sciences and Technology, University \\ of Jember, Jawa Timur, Indonesia \\ ${ }^{3}$ Faculty of Teacher Training and Education, University of Jember, Jember, East Java 68121, Indonesia \\ ${ }^{4}$ Center of Excellence for Biotechnology of Plant Industry (PU-BioTIn), University of Jember Indonesia \\ *For correspondence: hsaddy.faperta@unej.ac.id \\ Received 07 December 2019; Accepted 18 February 2020; Published 10 December 2020
}

\begin{abstract}
Bacterial leaf blight (BLB) is a disease caused by Xanthomonas oryzae pv. oryzae (Xoo) of rice in rice-producing countries including Indonesia and attack rice in all stages of growth. In the advanced, crop production will be decreased by up to 50 $70 \%$. Recently, the practical efforts to overcome the problem by using resistant varieties, antibiotics, and sanitation; however, the ability of the pathogen to forms the new virulent pathotypes is noteworthy. Alternatively, the pathogen could be environmental-friendly controlled by utilizing bacteriophages as biological control agents because of their specific characteristics to their bacterial hosts. This research aimed to obtain information about the characteristic of the first isolated bacteriophages from Indonesia. The result showed that two bacteriophages had been isolated from soil in Arjasa Jember and soil in Gadingan Situbondo, namely phage XooX1IDN and phage XooX2IDN, respectively. The two phages were inactivated at $80^{\circ} \mathrm{C}$ and stable at $\mathrm{pH}$ within the range of 6 to 8 . The phage XooX1IDN has a genome size of approximately $39 \mathrm{~kb}$, while phage XooX2IDN had a genome size $38 \mathrm{~kb}$. Morphologically, both phages possessed the family of Myoviridae. Phage biocontrol in vitro assay showed that both phages significantly reduced the growth of BLB pathogen, indicating that both phages potentially, as biological control agents for BLB disease in rice. (C) 2021 Friends Science Publishers
\end{abstract}

Keywords: Bacterial leaf blight; Phage therapy; Myoviridae; Xanthomonas oryzae

\section{Introduction}

Xanthomonas oryzae pathovar (pv.) oryzae (Xoo) is a Gram-negative bacterium found in field of rice-producing countries including Indonesia. This bacterium is a causative agent of bacterial leaf blight (BLB), a destructive bacterial disease that is prevalent among various rice varieties in the rice growing countries including Indonesia (Singh et al. 2015). Since the pathogen multiplies in xylem and predominantly invades the vascular tissue, the most common symptom of this disease is wilting, especially in young leaves namely "Kresek" disease and decrease rice production (Nino-Liu et al. 2006). BLB remains a serious problem on rice production, especially in Asia where the infection of pathogen results in enormous losses of yield ranging 6 to 90 percents in some rice varieties (Singh et al. 1980; Bhutto et al. 2018).

Numerous studies have reported the management strategies of bacterial leaf blight such as chemical control, genetic resistance, and biological control (Kim et al. 2016). A number of studies have reported plant genes that confer resistance against $X$. oryzae through the plant breeding using series of resistance gene ( $\mathrm{R}$ genes), designated from the $\mathrm{Xa}$ genes of rice cultivars (Degrasi et al. 2010). Unfortunately, this strategy is ineffective due to the ability of BLB pathogen to form a new and more virulent pathotypes because of Xoo's diversity and gene mutation mechanism of $X$. oryzae to breakdown the resistance genes of rice (Keller et al. 2000; Ponciano et al. 2003; Shanti et al. 2010). Biological control thus seems to be an alternative way to manage this disease being cost-effectively, sustainable and eco-friendly (Gnanamanickam 2009). Among the alternative of biological control agent, the use of bacteriophage could be a promising control technique, known as phage therapy (Addy et al. 2012a).

Bacteriophage is a virus that infects and multiplies within bacterial host cells, causing lysis along with the development of bacteriophage particles in specific host cells, and attacks a narrow bacterial strain (Beaudoin et al. 2007). Recently, the use of the phage as an approch to control bacterial pathogens has been highly attractive since some reports proved the potency of phage to control it 
bacterial host (Svircev et al. 2018). Ralstonia phage RsoM1USA has been found to have ability to inhibit the growth of Ralstonia solanacearum, a bacterial wilt pathogen on several crops (Addy et al. 2019). Moreover, Ahmad et al. (2014) isolated CP1 and CP2 bacteriophages that were able to control $X$. axonopodis pv citri on citrus. Mostly, bacteriophage can be easily isolated from the soil and irrigation water around infected crops (Bielke et al. 2012; Kalpage and Costa 2014) and from the symptomatic plant parts (Ritchie and Klos 1977).

Although, bacteriophage is easy to explore; however, the selection of bacteriophage isolates become crucial point in exploitation of bacteriophage for phage therapy (Addy et al. 2012a; Svircev et al. 2018). It is because bacterial host cells exhibit the changes in virulence after infection by the phage such as production of plant toxin and increase in virulence factors (Verheust et al. 2010). For example, infection of Ralstonia phage RSS1 increases the virulence of $R$. solanacearum to be more destructive on tomato (Addy et al. 2012b). In contrast, phage XacF1 decreases the virulence of Xanthomonas axonopodis pv citri to infect citrus leaves (Ahmad et al. 2014).

Several studies have been reported to explore bacteriophage as biological control agent of $X$. oryzae $\mathrm{pv}$. oryze. About 10 bacteriophages have been isolated from Vietnam and Thailand (Kovács et al. 2019), China (Dong et al. 2018), Japan (Kuo et al. 1967) and India (Ranjani et al. 2018). None of the study has been reported on the bacteriophage of $X$. oryzae isolated from Indonesia. Therefore, this study is aimed to explore the bacteriophage as an initial step prior to its use as biological control agents for the first time from Indonesia.

\section{Materials and Methods}

\section{Bacterial strain}

Xanthomonas oryzae XooJ2 was isolated from the infected rice leaves (56-day-old plant after transplanting) in the rice field showing "Kresek" symptoms and was routinely cultured on yeast extract dextrose agar (YDA) at $28^{\circ} \mathrm{C}$ for $72 \mathrm{~h}$. The bacterium was confirmed through several biochemical tests such as the $\mathrm{KOH}$ solubility assay, catalase test, starch hydrolysis assay, and pathogenicity test using cultivar Logawa (Schaad et al. 2001). In addition, confirmation was done by detecting the presence of specific gene sequence in $X$. oryzae pv. oryzae was done through polymerase chain reaction (PCR) using specific pair primer of JLXoo-230F (5'-CCT CTA TGA GTC GGG AGC-3') and JLXoo-230R (5'-ACA CCG TGA TGC AAT GAA GA -3 ). The GoTag PCR mixture (Promega, USA) was subjected to a 35 cycles after pre-denaturation at $96^{\circ} \mathrm{C}$ for 5 min, followed by denaturation at $96^{\circ} \mathrm{C}$ for $1 \mathrm{~min}, 55^{\circ} \mathrm{C}$ for 3 min, $72^{\circ} \mathrm{C}$ for $1 \mathrm{~min}$, and a final extension step at $72^{\circ} \mathrm{C}$ for 7 min. The PCR product was subjected to gel electrophoresis in a $1.5 \%(\mathrm{wt} / \mathrm{vol})$ agarose gel in TAE, followed by staining with ethidium bromide (Lu et al. 2014).

\section{Isolation and purification of xanthomonas infecting bacteriophages}

One gram of soil samples, collected from rice fields in District Arjasa, Regency, Jember and District Gadingan, Regency Situbondo, East Java Province, Indonesia, were used for phage isolation using the basic enrichment method (Addy et al. 2019). Briefly, soil sample was suspended with $2 \mathrm{~mL}$ of sterile water and shaken for $24 \mathrm{~h}$. One milliliter of suspension was taken and filtered through $0.45-\mu \mathrm{m}$ membrane filter (Steradisc, Krabo Co., Japan) and use as phage lysate in plaque assay with XooJ2 as host. Bacteriophages were then purified as described by (Ahmad et al. 2017). Routinely, 24 h-old bacterial culture was used as host for phage's propagation. Pure bacteriophage particles were stored at $4^{\circ} \mathrm{C}$ until used in further testing (Addy et al. 2019). The morphology of phages was assessed by transmission electron microscopy.

\section{Nucleic acid digestion and protein profile}

To determine the nucleic acid type of bacteriophages, the genome of bacteriophages was digested with EcoRV restriction enzyme according to the supplier's instructions (Promega, USA). Eight microliters of phage DNA suspension was mixed with $9.5 \mu \mathrm{L}$ sterile distilled water, 2 $\mu \mathrm{L}$ enzyme buffer and $0.5 \mu \mathrm{L}$ restriction enzyme (EcoRV or $X b a \mathrm{I})$ the mixture was incubated at $37^{\circ} \mathrm{C}$ for $60 \mathrm{~min}$. DNA fragments were subjected to gel electrophoresis in $1 \%$ agarose gel.

To determine the protein profile, whole phage particles were subjected to Sodium Dedoxyl Sulphate Polyacrylamide Gel Electrophoresis (SDS-PAGE) analysis. Briefly, whole phage particles were harvested using ultracentrifuge (Hitachi, Japan) at $4^{\circ} \mathrm{C}, 30.000 \times \mathrm{g}$ for $2 \mathrm{~h}$ and equal volumes of sample buffer $(0.5 \mathrm{M}$ Tris- $\mathrm{HCl}(\mathrm{pH}$ 7.2) buffer containing 4\% SDS, $10 \% \beta$-mercaptoethanol, $20 \%$ glycerol, and $0.1 \%$ bromophenol blue) was added. The samples were boiled for $5 \mathrm{~min}$. Gel was then stained and visualized using Coomassie brilliant blue dye.

\section{Host specificity assay}

To determine the host specificity of phage XooX1IDN and XooX2IDN, the purified phage was subjected to spot testing using XooJ2 and $R$. solanacearum DT3 as the bacterial target. In this test, three microliters of the phage suspension $\left(10^{3} \mathrm{PFU} / \mathrm{mL}\right)$ was spotted on top of the double-layered YDA plate. The formation of a clear zone on the spotting area indicated that the bacterium were susceptible to the phage. Potentially susceptible strains were tested further by serial dilution plaque assay to determine whether they were truly susceptible to the phage (Ahmad et al. 2017).

\section{Bacteriophages stability assays}

Xanthomonas phages were tested for their stability against 
environmental factors such as temperature and $\mathrm{pH}$ (Iriarte $e t$ al. 2007). To determine the effect of temperature on the stability and infectivity of bacteriophages, the purified phage particles in SM buffer were incubated at different temperatures, $30^{\circ} \mathrm{C}$ to $80^{\circ} \mathrm{C}$. While to determine the effect of $\mathrm{pH}$, bacteriophage particles in SM buffer was adjusted to reach various $\mathrm{pH}$ of 3 to 9 followed by incubation at room temperature. Phage number was estimated by calculating plaque on the YDA plate using isolate $\mathrm{XooJ} 2$ as a host.

\section{Biological control assay in vitro}

To determine the effect of phages on XooJ2 (susceptible host), the growth of XooJ2 in NB medium (in 24-well plates) at $28^{\circ} \mathrm{C}$ was monitored on the phage XooX1IDNand XooX2IDN-treated and untreated XooJ2. Briefly, the concentration of the overnight culture of XooJ2 was adjusted with $\mathrm{NB}$ to initial $\mathrm{OD}_{600}$ of 0.3 , and $1.5 \mathrm{~mL}$ of the bacterial suspension was added to each well of the 24-well plate. One hundred and fifty microliters of phage suspension was then added at m.o.i of $0.01,0.1,1.0$, and 10, respectively, and the plate was incubated inside Microplate reader SH-1000 (Corona Electric, Japan) with slow shaking. SM buffer was used as a phage control (m.o.i of 0). Bacterial growth was estimated by measuring the absorbance at $600 \mathrm{~nm}$ every $180 \mathrm{mins}$ for $36 \mathrm{~h}$. This experiment was repeated three times with three replications for each m.o.i treatment (Addy et al. 2019).

\section{Results}

\section{The bacterial leaf blight pathogen}

The isolate XooJ2 was isolated from 56-day-old rice from the symptomatic leaf of bacterial leaf blight in Jember. The isolate $\mathrm{XooJ} 2$ was purified and characterized by its biochemistry and molecular properties. The bacterium XooJ2 exhibited yellow, round in shape, convex, smooth surface, and flat edge colonies when grown on Nutrient Agar (NA) media (Fig. 1A). Furthermore, the genome of XooJ2 was subjected to PCR amplification using the Xanthomonas oryzae pv. oryzae specific PCR primer and resulted in the predicted band with an approximate size of $230 \mathrm{bp}$ (Fig. 1B). The isolate XooJ2 also produced leaf blight symptoms after re-inoculation to the rice leaf (Fig. 1C).

\section{Morphology plaques and phages, nucleic acid, and protein profile}

Phage XooX1IDN and XooX2IDN, isolated from rice fields in Jember and Situbondo, showed turbid plaques (diameter $2 \pm 1 \mathrm{~mm}$ ) on tested medium (Fig. 2). Transmission electron microscope revealed similar tailed forms of both phages (Fig. 3). Analysis of protein bands patterns through SDSPAGE showed that all bacteriophages had a similar composition of more than 10 sub-units of protein (Fig. 4A).
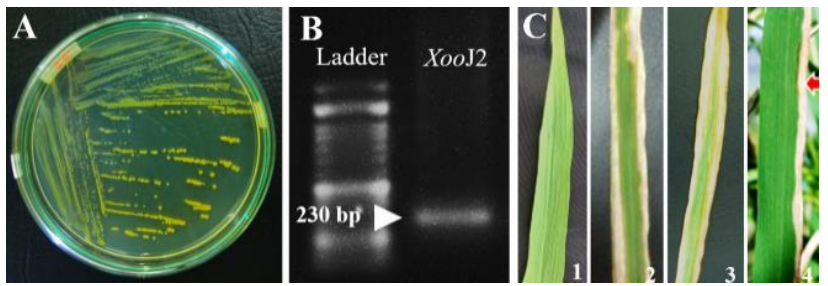

Fig. 1: Partial characteristic of bacterial host XooJ2, a pathogen of bacterial leaf blight on rice. XooJ2 colonies on YDA medium exhibit yellow colonies (A), agarose gel electrophoresis of PCR product of $230 \mathrm{bp}$ using specific pair primer (B), and The leaves exhibit bacterial leaf blight symptoms in the field and the result of the reinoculation assay $(\mathbf{C})$

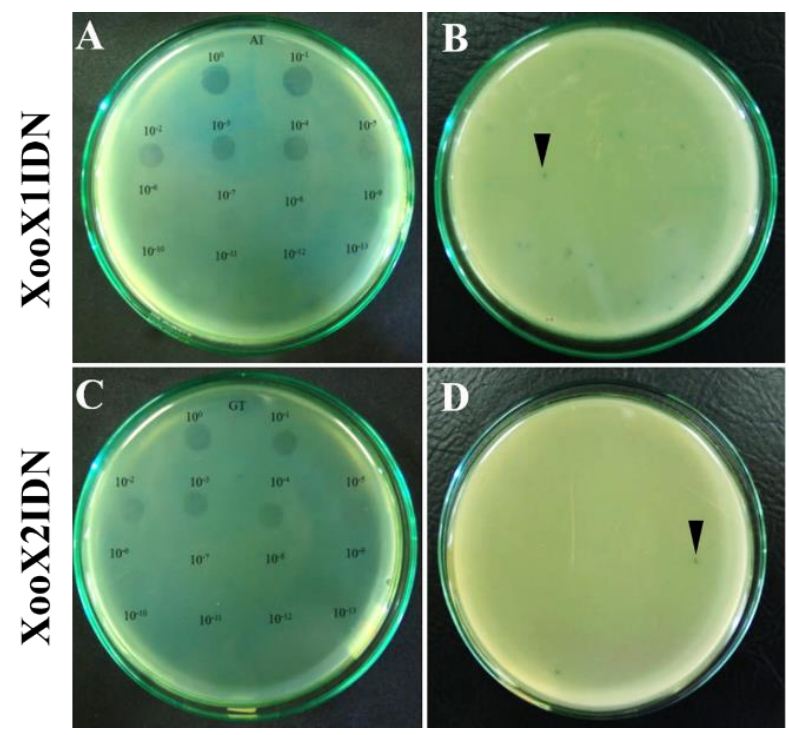

Fig. 2: Plaques morphology of phage XooX1IDN and XooX2IDN on tested media
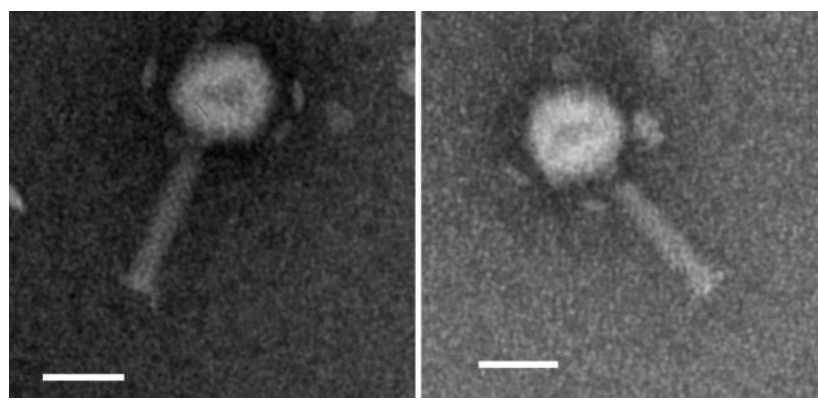

Fig. 3: Transmission electron microscopy of negatively stained (A) XooX1IDN and (B) XooX2IDN particles at 50-k fold magnification and at an acceleration voltage of $80 \mathrm{kV}$. Scale bar represents $50 \mathrm{~nm}$

The genome of both bacteriophages of non-digested endonuclease was more than $10,000 \mathrm{bp}$ and was clearly digested with DNAse and endonuclease restriction enzymes, but not RNAse (Fig. 4B). Moreover, EcoRV restriction enzyme provided similar patterns except for the particular 

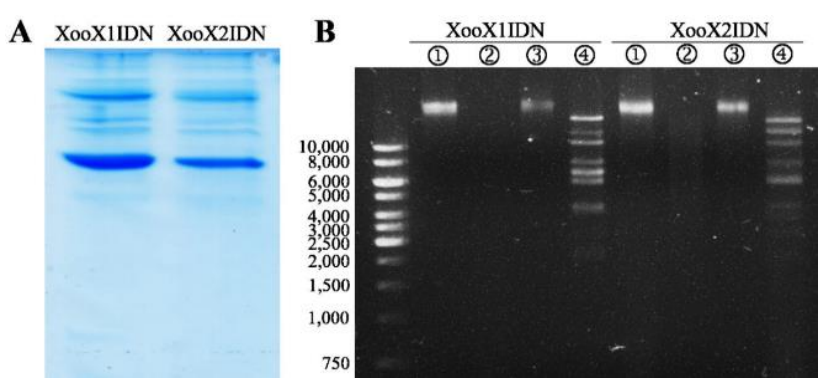

Fig. 4: Analysis of phage XooX1IDN and XooX2IDN characteristics. (A) Structural protein profile of phage particles on SDS-PAGE, (B) Restriction profile of phages nucleic acid (1) after digestion with DNAseI (2), RNAseA (3), and endonuclease EcoRV (4)
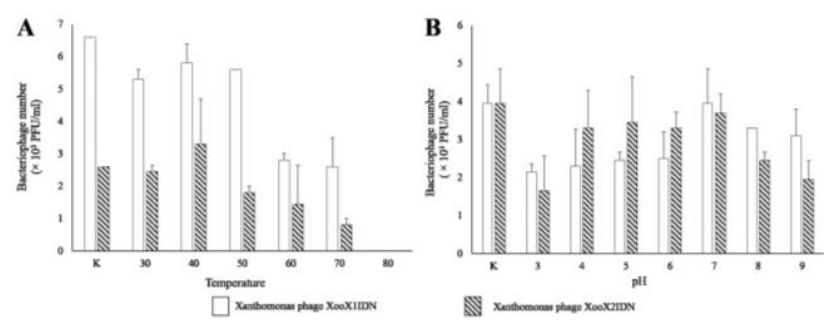

Fig. 5: Effect of (A) temperature and (B) $\mathrm{pH}$ on the phage XooX1IDN and XooX2IDN particles stability

band around $7.0 \mathrm{kbp}$ (Fig. 4B, lane 4) and was predicted to have a genome size of approximately about $39 \mathrm{kbp}$ for phage XooX2IDN and about $38 \mathrm{~kb}$ for phage XooX2IDN.

\section{Effect of temperature, pH and host specificity}

Some environmental factors such as temperature and $\mathrm{pH}$ contribute to the inactivation of bacteriophage particles. The result showed that the number of phage XooX1IDN and XooX2IDN particles began to decrease after incubation of both phages at $60^{\circ} \mathrm{C}$ and no bacteriophage particles were detected by incubating the particles at $80^{\circ} \mathrm{C}$ (Fig. 5A). Moreover, the phage XooX1IDN and XooX2IDN still formed plaques although the particles have preincubated in suspensions of different $\mathrm{pH}$ levels (Fig. 5B). In addition, both phages, XooX1IDN and XooX2IDN only formed plaques on XooJ2 lawn but not on $R$. solanacearum DT3.

\section{Inhibition of XooJ2 growth by XooX1IDN and XooX2IDN in vitro}

To evaluate the ability of phage XooX1IDN and XooX2IDN to lyse XooJ2 in liquid culture, a growth inhibition assay of host XooJ2 was performed as described under "Materials and Methods". The result showed that all XooJ2 cultures treated with phages (at all m.o.i) were less turbid compare to the XooJ2 culture without phages treatment (Fig. 6A). When XooJ2 cultures were initially

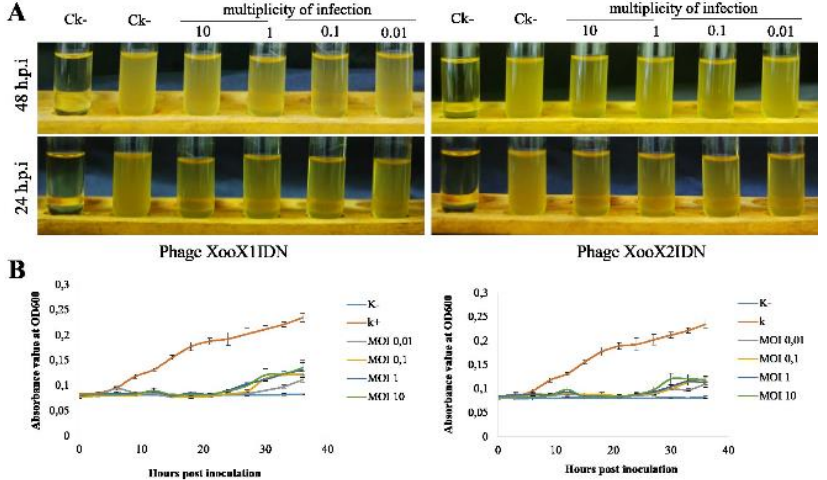

Fig. 6: Effects of phage XooX1IDN and XooX2IDN on the growth of XooJ2. (A) The XooJ2 growth characteristic in NB medium inoculated with phage XooX1IDN and XooX2IDN at different multiplicity of infection (m.o.i). Controls were medium with $(\mathrm{Ck}+)$ and without the host XooJ2 (Ck-). The culture turbidity was observed at $24 \mathrm{~h}$ (bottom) and $48 \mathrm{~h}$ (upper) after phage inoculation. (B) The growth curve of XooJ2 after inoculation with bacterial host and phage at m.o.i of 0 (red), 0.01 (green), 0.1 (purple), 1 (blue), and 10 (orange), respectively. The XooJ 2 cell density was monitored by measuring the absorbance at $600 \mathrm{~nm}$ every $3 \mathrm{~h}$ for $36 \mathrm{~h}$. The data are presented as the means from four replications for each m.o.i treatment. The error bars indicate the standard deviation

infected with phages (at all m.o.i) of both XooX11IDN and XooX2IDN, growth of the XooJ2 was inhibited until 24 to $27 \mathrm{~h}$ post-inoculation compared to control that the growth that was initially detected $6 \mathrm{~h}$ post-inoculation. Moreover, the growth of XooJ2 in liquid NB was significantly lower than in the cultures treated with the phage XooX1IDN and XooX2IDN. However, the turbidity of XooJ2 cultures treated with both phages at different m.o.i was not at significant level, compared to other m.o.is (Fig. 6B).

\section{Discussion}

Phages XooX1IDN and XooX2IDN are the first Xooinfecting phages isolated from soil in rice field of Jember and Situbondo, Indonesia. Both bacteriophages were studied further, such as stability on temperatures, $\mathrm{pH}$, plaque and particle morphology, host specificity, genome size, and structural protein profile. According to the transmission electron microscope examination, all phages have a phage morphology similar to phage having head and noncontractile tail (presented by short neck; Fig. 3). In addition, both phages, XooX1IDN and XooX2IDN are also possessed typical nucleic acid of myovirus that is doublestranded DNA with an average genome size of about 38-39 kb (Fig. 4). According to the morphology and nucleic acid type as mentioned on the guidelines of the International Committee on Taxonomy of Viruses (ICTV) (Ackermann 2003), all phages possess head and tailed particles may belong to the families of Myoviridae, Siphoviridae, or Podoviridae (Order Caudovirales). Moreover, phages 
characterized by head and non-contractile tail (possesses short or long neck) commonly belong to the family of Myoviridae. The similar morphology and genome type were also reported to that myoviruses isolated from paddy field in China (Chae et al. 2014; Dong et al. 2018; Ogunyemi et al. 2019), phages isolated from tomato field in United State of America (Addy et al. 2019), or phage isolated from tomato in Japan (Fujiwara et al. 2008), which exhibited head and non-contractile tail phage particles.

The thermal stability of bacteriophages showed that the phage infectivity drastically decreased at the temperature of $60^{\circ} \mathrm{C}$ or more (Fig. 5A). Moreover, bacteriophages were completely lost their infectivity after incubation at a temperature of $80^{\circ} \mathrm{C}$. Probably this condition may occur because the relationship of cross sulfide in the capsid protein of denatured bacteriophages at higher temperatures results in a loss of bacteriophage integrity (Jończyk et al. 2011). In the study, it was also revealed that all bacteriophages remained stable after treatment at various $\mathrm{pH}$ conditions, both in acidic and basic conditions, as the bacteriophage infectivity was still maintained even though it was treated at various $\mathrm{pH}$ levels (Fig. 5B). However, bacteriophages tend to be more stable in a $\mathrm{pH}$ range of 6 to 8. This phenomenon was also reported for the phage XOF4 that remained stable after growth at $\mathrm{pH}$ range of 6 to 8 (Ranjani et al. 2018). Temperature and $\mathrm{pH}$ contribute to the inactivation of bacteriophage particles by damaging their structural elements (Nobrega et al. 2016), phage aggregation, and ability to penetrate host cells (Langlet et al. 2007). On the other hand, phage XooX1IDN and XooX2IDN are the specific phages that infect only $X$. oryzae. This is typical phenomenon of bacteriophage and become the advantage of using phage as biological control agents since the phage only infect very narrow and specific bacterial strain (Dong et al. 2018; Elhalag et al. 2018; Ranjani et al. 2018).

The potency of phage XooX1IDN and XooX2ID to control XooJ2 was also tested to see how potent these two bacteriophages were, in suppressing the growth of the host $\mathrm{XooJ}$ 2, qualitatively and quantitatively. The results demonstrated that XooX1IDN and XooX2IDN were able to control and inhibit the growth of $X$. oryzae. Although some cells showed steady growth phenomena, however, the cells growth remained significantly lower than control (Fig. 6), which indicates that equilibrium between lysis and cell growth was established or that phage-resistant cell growth rate might be decreased resulting the host population at a relatively low level. A similar result was previously reported for phage $\Phi$ RSL1 infecting $R$. solanacearum (Fujiwara et al. 2011), phage Xoo-sp2 infecting $X$. oryzae (Dong et al. 2018 ), or phage RsoM1USA infecting $R$. solanacearum (Addy et al. 2019).

Utilization and use of phage for biological control strategy have been widely reported as phage therapy against pathogenic bacteria (Fujiwara et al. 2011; Addy et al. 2012a; Elhalag et al. 2018). This phage therapy should contribute to enhancing the advantages of controlling bacterial leaf blight and reducing the use of conventional pesticides, which are harmful to the environment, human and animal health. Therefore, several steps must be examined during phage exploitation as biological control agent. All begins from the analysis of phage-host interaction in vitro followed by in vivo assay (Addy et al. 2012a). In this study, it is suggested that phage XooX1IDN and XooX2IDN have the potency to be used in controlling bacterial leaf disease. However, Dong et al. (2018) suggested that several studies must be done before utilize the phage for biocontrol to increase safety and sufficient implementation such as the host range, safety aspect of phage application, and mass production condition of phages. Therefore, some studies still needed to ensure that phage XooX1IDN and XooX2IDN are the best phages for phage therapy against bacterial leaf blight disease on rice, especially in Indonesia.

\section{Conclusion}

The XooX1IDN and XooX2IDN are the first Xanthomonas oryzae infecting bacteriophages that belongs to the family of Myoviridae and have a double-stranded DNA as genome with approximately about $39 \mathrm{~kb}$ and $38 \mathrm{~kb}$ in size. The bacteriophages remain stable by growth at maximum temperature of $60^{\circ} \mathrm{C}$, indicating that these bacteriophages are suitable to use as biological control agent of bacterial leaf blight on rice.

\section{Acknowledgments}

This research was supported by Grant from The Directorate of Research and Community Service-Ministry of Research, Technology, and Higher Education Republic of Indonesia with contract number 175/SP2H/LT/DRPM/2019.

\section{Author Contributions}

All authors conceived and designed the research; DR performed the experiment; HSA and DR analysed the data and wrote the paper.

\section{References}

Ackermann HW (2003). Bacteriophage observations and evolution. Res Microbiol 154:245-251

Addy HS, AA Ahmad, Q Huang (2019). Molecular and biological characterization of Ralstonia phage RsoM1USA, a new species of P2virus, isolated in the USA. Front Microbiol 10:267-268

Addy HS, A Askora, T Kawasaki, M Fujie, T Yamada (2012a). Utilization of filamentous phage $\varphi$ RSM3 to control bacterial wilt caused by Ralstonia solanacearum. Plant Dis 96:1204-1209

Addy HS, A Askora, T Kawasaki, M Fujie, T Yamada (2012b). The filamentous phage $\varphi$ RSS1 enhances virulence of phytopathogenic Ralstonia solanacearum on tomato. Phytopathology 102:244-251

Ahmad AA, MJ Stulberg, JP Mershon, DS Mollov, Q Huang (2017). Molecular and biological characterization of $\phi$ Rs551, a filamentous bacteriophage isolated from a race 3 biovar 2 strain of Ralstonia solanacearum. PLoS One 12; Article e0185034 
Ahmad AA, M Ogawa, T Kawasaki, M Fujie, T Yamada (2014). Characterization of bacteriophages $\mathrm{Cp} 1$ and $\mathrm{Cp} 2$, the strain-typing agents for Xanthomonas axonopodis pv. citri. Appl Environ Microbiol 80:77-85

Beaudoin RN, DR DeCesaro, DL Durkee, SE Barbaro (2007). Isolation of a bacteriophage from sewage sludge and characterization of its bacterial host cell. Riv Acad J 3:1-8

Bhutto SH, JA Tariq, RN Syed, GH Jatoi (2018). Isolation and characterization of bacteria isolated from the rice crop in lower Sindh. Pak J Biotechnol 15:151-154

Bielke LR, G Tellez, BM Hargis (2012). Successes and Failures of Bacteriophage Treatment of Enterobacteriaceae Infections in the Gastrointestinal Tract of Domestic Animals, pp:159-178. InTech Bacteriophages. IntechOpen, London

Chae JC, NB Hung, SM Yu, HK Lee, YH Lee (2014). Diversity of bacteriophages infecting Xanthomonas oryzae pv. oryzae in paddy fields and its potential to control bacterial leaf blight of rice. $J$ Microbiol Biotechnol 24:740-747

Degrasi G, G Devescovi, J Bigirimana, V Venturi (2010). Xanthomonas campestris pv. oryzae. XKK.12 contains and AroQy chorismate mutase that is involved in rice virulence. Phytopathology 100:262-270

Dong Z, S Xing, J Liu, X Tang, L Ruan, M Sun, D Peng (2018). Isolation and characterization of a novel phage Xoo-sp2 that infects Xanthomonas oryzae pv. oryzae. J Gen Virol 99:1453-1462

Elhalag K, M Nasr-Eldin, A Hussein, A Ahmad (2018). Potential use of soilborne lytic Podoviridae phage as a biocontrol agent against Ralstonia solanacearum. J Basic Microbiol 58:658-669

Fujiwara A, M Fujisawa, R Hamasaki, T Kawasaki, M Fujie, T Yamada (2011). Biocontrol of Ralstonia solanacearum by treatment with lytic bacteriophages. Appl Environ Microbiol 77:4155-4162

Fujiwara A, T Kawasaki, S Usami, M Fujie, T Yamada (2008). Genomic characterization of Ralstonia solanacearum phage $\phi$ RSA1 and its related prophage $(\phi \mathrm{RSX})$ in strain GMI1000. J Bacteriol 190:143-156

Gnanamanickam SS (2009). An overview of progress in biological control. Biol Contr Rice Dis 8:43-51

Iriarte FB, B Balogh, MT Momol, LM Smith, M Wilson, JB Jones (2007). Factors affecting survival of bacteriophage on tomato leaf surfaces. Appl Environ Microbiol 73:1704-1711

Jończyk E, M Kłak, R Międzybrodzki, A Górski (2011). The influence of external factors on bacteriophages. Folia Microbiol 56:191-200

Kalpage MD, DM Costa (2014). Isolation of bacteriophages and determination of their efficiency in controlling Ralstonia solanacearum causing bacterial wilt of tomato. Trop Agric Res 26:140-151

Keller BC, Feuillet, M Messmer (2000). Basic Concepts and Application in Resistance Breeding Mechanism of Resistance to Plant Disease. Kluwer Academic Publisher, London, UK
Kim SI, JT Song, JY Jeong, HS Seo (2016). Niclosamide inhibits leaf blight caused by Xanthomonas oryzae in rice. Sci Rep 6; Article 21209

Kuo TT, TC Huang, RY Wu, CM Yang (1967). Characterization of three bacteriophages of Xanthomonas oryzae (Uyeda et Ishiyama) Dowson. Bot Bull Acad Sin 8:246-254

Langlet J, F Gaboriaud, C Gantzer (2007). Effects of pH on plaque forming unit counts and aggregation of MS2 bacteriophage. J Appl Microbiol 103:1632-1638

Lu W, L Pan, H Zhao, Y Jia, Y Wang, X Yu, X Wang (2014). Molecular detection of Xanthomonas oryzae pv. oryzae, Xanthomonas oryzae pv. oryzicola, and Burkholderia glumae in infected rice seeds and leaves. Crop J 2:398-406

Nino-Liu D, P Ronald, A Bogdanove (2006). Xanthomonas oryzae pathovars: Model pathogens of a model crop. Mol Plant Pathol 7:303-324

Nobrega FL, AR Costa, JF Santos, MF Siliakus, JWV Lent, SW Kengen, J Azeredo, LD Kluskens (2016). Genetically manipulated phages with improved $\mathrm{pH}$ resistance for oral administration in veterinary medicine. Sci Rep 6; Article 39235

Ogunyemi SO, J Chen, M Zhang, L Wang, MMI Masum, C Yan, L An, B $\mathrm{Li}$, J Chen (2019). Identification and characterization of five new OP2-related Myoviridae bacteriophages infecting different strains of Xanthomonas oryzae pv. oryzae. J Plant Pathol 101:263-273

Ponciano G, H Ishihara, S Tsuyumu, JE Leach (2003). Bacterial effectors in plant disease and defense: Keys to durable resistance. Plant Dis $87: 1272-1282$

Ranjani P, Y Gowthami, SS Gnanamanickam, P Palani (2018) Bacteriophages: A new weapon for the control of bacterial blight disease in rice caused by Xanthomonas oryzae. Microbiol Biotechnol Lett 46:346-359

Ritchie DF, EJ Klos (1977). Isolation of Erwinia amylovora bacteriophage from aerial parts of apple trees. Phytopathology 67:101-104

Schaad N, JB Jones, W Chun (2001). Laboratory Guide for Identification of Plant Pathogenic Bacteria, APS Press, St. Paul, Minnesota, USA

Shanti ML, VV Shenoy, GL Devi, VM Kumar, P Premalatha, GN Kumar, HE Shashidhar, UB Zehr, WH Freeman (2010). Marker-assisted breeding for resistance to bacterial leaf blight in popular cultivar and parental lines of hybrid rice. J Plant Pathol 92:495-501

Singh RA, B Das, KM Ahmed, V Pal (1980). Chemical control of bacterial leaf blight of rice. Intl J Pest Manage 26:21-25

Singh S, S Chand, NK Singh, TR Sharma (2015). Genome-Wide Distribution, Organization and functional characterization of disease resistance and defence response genes across rice species. PLoS One 10; Article e0125964

Svircev A, D Roach, A Castle (2018). Framing the Future with Bacteriophages in Agriculture. Viruses 10:218-230

Verheust C, K Pauwels, J Mahillon, DR Helinski, P Herman (2010). Contained use of bacteriophages: Risk assessment and biosafety recommendations. Appl Biosafe 15:32-44 